\title{
Formal sector subcontracting and informal sector employment in Indian manufacturing
}

\author{
Ana I Moreno-Monroy ${ }^{1}$, Janneke Pieters ${ }^{2,3^{*}}$ and Abdul A Erumban ${ }^{4,5}$
}

\author{
* Correspondence: \\ janneke.pieters@wur.nl \\ ${ }^{2}$ Wageningen University, \\ Hollandseweg 1, Wageningen, The \\ Netherlands \\ ${ }^{3}$ IZA, Schaumburg-Lippe-Strasse 5-9, \\ Bonn, Germany \\ Full list of author information is \\ available at the end of the article
}

\begin{abstract}
Using nationally representative survey data of Indian manufacturing enterprises spanning the period 1995-2006, we analyze the link between formal sector subcontracting and informal sector employment. A novelty in our analysis is that this relationship is allowed to differ between modern and traditional segments of the informal sector. We show that formal sector subcontracting is positively related to employment growth only in the most modern segments of the informal sector. Increased subcontracting cannot explain the persistently high employment in traditional informal manufacturing activities in India. Instead, subcontracting can contribute to job creation in relatively modern segments of the informal sector.

JEL codes: J21, 014, 017

Keywords: Informal sector; Subcontracting; Employment; Manufacturing; India
\end{abstract}

\section{Introduction}

In developing countries, a large proportion of employment and output generation are concentrated in the informal sector (Schneider et al. 2010). Even in countries experiencing strong economic growth, the informal sector often remains large and relatively unproductive, pulling down labor productivity and aggregate economic growth (Khaturia et al. 2013; De Vries et al. 2012). One of the key aspects in understanding the evolution of the informal sector is its interaction with the formal sector (Hart 1973; Weeks 1975; Ranis and Stewart 1999; Davies and Thurlow 2010). An important way in which formal enterprises interact with informal enterprises is through subcontracting, which has gained relevance in times of increased competition brought about by trade liberalization and globalization (ILO and WTO 2009). To date, however, there is little empirical evidence about the relationship between subcontracting and employment in the informal sector in developing countries.

The existing literature in this area can be broadly divided into two views. The first one, hereafter referred to as the stagnation view, contends that formal enterprises subcontract the most labor-intensive production activities to traditional informal enterprises in order to minimize labor costs. Due to intense pressure for cost competition exerted on informal enterprises, the linkages between formal and informal enterprises result in the recreation of the survivalist characteristics of informal enterprises (Tokman 1978; Portes 1994). As the primary objective is to minimize labor costs, subcontracting linkages will be strongest between the formal sector and the most traditional segment of the informal sector. An 
increase in formal sector subcontracting will then be associated with employment growth in the most traditional informal sector activities. The second view, which we label the modernization view, holds that formal enterprises establish subcontracting relationships only with relatively modern informal enterprises, which can not only reduce the costs of production, but also meet their quality standards. Through formal-informal production links, then, formal sector subcontracting can be a vehicle for the modernization of the informal sector by stimulating growth of the modern segments of the informal sector (Ranis and Stewart 1999; Marjit 2003).

Our aim in this paper is to contrast the validity of these views empirically. That is, we investigate whether formal sector subcontracting is associated with growth of the traditional segments or with growth of the modern segments of the informal sector. This question is relevant to the broader question of the determinants of structural change in economies with large and heterogeneous informal sectors (see De Vries et al. 2012). Furthermore, our empirical findings, used in conjunction with firm-level and/or industry-specific studies, can inform the design of policies for improving the linkages between formal and informal manufacturing enterprises by indicating priority areas or sectors which could be subject to interventions.

Using a state-industry panel constructed from nationally representative enterpriselevel survey data, we study the formal-informal ${ }^{1}$ subcontracting relationship in Indian manufacturing during the period 1995-2006. Competitive pressure in the Indian manufacturing sector increased as a consequence of the reforms undertaken in the late 1980s and early 1990s that abolished licensing requirements for most industries and the liberalization of international trade and foreign investment (Kotwal et al. 2011). The regulation of labor markets, however, has been left largely untouched and constitutes an important difference between the formal and informal sector. Pressure to cut costs and increase flexibility, together with strict labor laws affecting only formal enterprises, form clear incentives for formal enterprises to subcontract activities to the informal sector (Ramaswamy 1999; Mazumdar and Sarkar 2008; Siggel 2010). During the period we analyze, subcontracting by formal enterprises increased substantially, while informal sector employment persisted to account for almost 90 percent of employment and 40 percent of value added in the manufacturing sector. Besides the literature on formal-informal production linkages, the paper also contributes to a growing literature that analyzes the evolution of India's informal sector (Ghani et al. 2014, 2013; Mukim 2011; Sundaram et al. 2012), but which has not yet focused explicitly on formalinformal subcontracting linkages.

In India, as in many countries, the informal sector comprises a wide range of activities. In order to test whether formal subcontracting is associated with an expansion of the traditional versus the modern segments of the informal manufacturing sector, one needs to identify these segments. Because there is no agreement on the number of segments and the boundaries that define them (Grimm et al. 2012), we propose a continuous, multi-dimensional measure of modernity at the state-industry level. This modernity index is based on the start-of-period capital-labor ratio, location of enterprises, average number of hired workers per enterprise, and technical qualifications of enterprise owners.

Using these dimensions, we show that in the period 1995-2006, informal sector employment grew across all segments and was somewhat skewed towards more modern 
state-industries. Yet, the most traditional state-industries still account for the largest share of informal sector employment. Exploiting within-state-industry variation over time and controlling for state- and industry-specific trends, our estimation results show that growth of formal sector subcontracting is positively related to employment growth in modern informal activities, while no such relationship is found for the traditional segments. Although we cannot identify the causal effect of subcontracting on informal sector employment, we show that the relationship is unlikely to be driven by omitted variables, and we argue that reverse causality concerns are less pertinent- for if subcontracting is driven by informal sector expansion, this too is evidence of production linkages. Our findings support the modernization view of the informal sector and clearly indicate that persistently high employment in very traditional informal activities in India cannot be a direct result of increased subcontracting by the formal sector.

In the next section, the two views on the effects of formal sector subcontracting as well as the existing evidence for India are further discussed, providing the rationale for distinguishing modern and traditional segments in our analysis. Section three describes the data, measurement of variables, and patterns of employment growth. Section four present the empirical model. Section five discusses the main results and robustness checks, and section six concludes.

\section{Informal sector heterogeneity and formal sector subcontracting}

\subsection{Informal sector heterogeneity and modernization}

The informal sector is highly diverse. An 'informal enterprise' can be one consisting of a single worker performing simple manual work in the worker's own household with no machinery. It can also be an enterprise that operates in a plant, employing as much as 10 hired workers and using machinery. Evidently these two types of enterprises are not the same, even though they can both be labeled as 'informal'. For this reason, it is difficult to find a unique defintion of an 'informal enterprise' that can account for this heterogeneity.

Ranis and Stewart (1999) have proposed a relevant distinction between the traditional and modern segments of the informal sector, based on a number of characteristics of the informal enterprises that compose them. To understand this, it is useful to think of the informal enterprises along a continuum of 'modernity' dimensions, as represented in Figure 1. At the very bottom of the distribution are traditional informal enterprises that undertake very low value-added activities, operate within the premises of a household or having no fixed location, and use extremely low or no capital and/or hired labor. At the

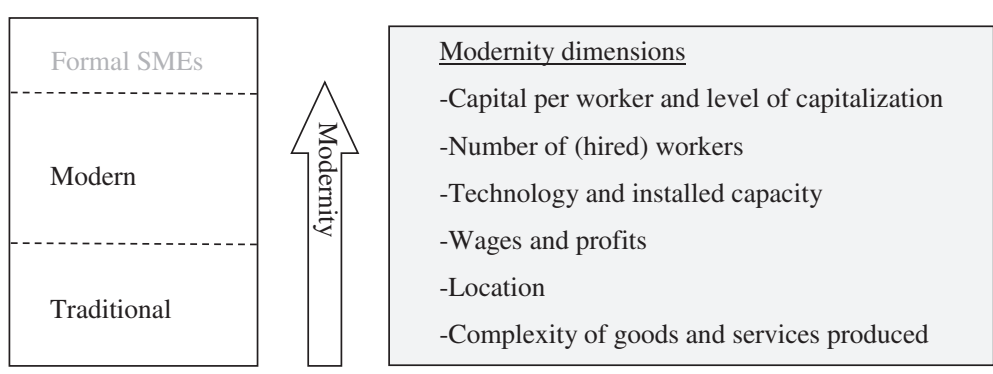

Figure 1 Informal enterprises along a modernity continuum. 
very top of the distribution are the informal enterprises that undertake relatively highvalue added activities, produce standardized goods and services, operate in a fixed location outside the household premises, and make use of some capital and low- and mediumskilled hired labor. Such enterprises offer competitive wages that are comparable to those offered in the formal sector. Informal enterprises at the very top of the distribution can be indistinguishable from formal Small and Medium Enterprises (SMEs), save the fact that they do not comply with all the legal regulations faced by the formal sector.

In the process of economic development, an increase of the relative size of the modern informal segment and a decline of the traditional segment can be described as the modernization of the informal sector. The existence of production linkages between informal and formal enterprises can speed up or deter the modernization of the informal sector (Ranis and Stewart 1999). In the case of formal-informal subcontracting linkages, these effects on the evolution of the informal sector can be summarized into two contrasting views found in the literature: the stagnation view and the modernization view.

\subsection{Two contrasting views on the effects of subcontracting}

Technically speaking, subcontracting can be described as a relationship between the parent enterprise which requests another independent enterprise who is the subcontractor (or ancillary industry in India) to undertake the whole or part of its activity instead of doing it by itself (Watanabe 1971). In such a relationship, the parent enterprise assumes the full responsibility for the quality of the final product that reaches the customer, which is often achieved by particular specifications provided to the subcontractor.

The theoretical positions on production linkages between formal and informal sector can be divided into the stagnation and the modernization views. According to the stagnation view, formal enterprises wishing to reduce labor costs subcontract activities to informal enterprises. By their superior status in terms of size and capital, formal enterprises are able to impose stringent conditions on informal enterprises regarding prices, thus extracting most of the value added. Under this type of formal-informal linkage, informal enterprises are unable to accumulate capital and are stagnated in a survivalist mode (Moser 1978; Tokman 1978; Portes 1994; Portes et al. 1989). In fact, formal enterprises can benefit from the 'race-to-the-bottom' in terms of labor costs in the informal sector, as it directly translates into higher profitability from subcontracting. As stagnant, survivalist informal enterprises are part of the traditional segment of the informal sector, an increase in the incidence of subcontracting would result in expansion of the traditional segment and thus work against the modernization of the informal sector. Conversely, expansion of subsistence self-employment (through ruralurban migration, for example) can provide a 'reserve army of workers' and thereby stimulate formal sector subcontracting.

A second view on production linkages, referred to as the modernization view, holds that formal enterprises engage in subcontracting relationships only with modern informal enterprises. Formal enterprises pursue three complementary aims when engaging in subcontracting: first, minimizing costs so that the price of the subcontracted activity is as low as possible; second, maximizing the quality of the subcontracted product, so as not to compromise quality standards; and third, minimizing the risk of vertically disintegrating the production process, so as to ensure a timely delivery of the final product. Therefore, 
formal enterprises take into account not only differences in costs between in-house production and subcontracting, but also the productive and technological capacity of potential suppliers (Wattanapruttipaisan 2002).

Ranis and Stewart (1999) start from the assumption that formal enterprises have intermediate linkages (including subcontracting) only with modern informal enterprises and show how formal sector growth can lead to modernization of the informal sector. Growth of formal sector output or an increase in the subcontracting intensity of formal sector production leads to the expansion of output and labor demand in the modern informal segment. In a similar vein, Marjit (2003) emphasizes segmentation within the informal sector and argues that only the capital-intensive segment is complementary to the formal sector. In his general equilibrium model, the formal sector uses an intermediate input produced by the capital-intensive (modern) segment of the informal sector. Output growth in the formal sector leads to an expansion of this capital-intensive informal segment through increased demand for its output.

There is descriptive evidence for Kenya and a number of West African countries showing that, in line with the modernization view of Ranis and Stewart (1999) and Marjit (2003), informal enterprises with more capital, higher productivity, and more highly educated workers are more likely to have a forward production link with the formal sector (House 1984; Arimah 2001; Boehme and Thiele 2012). It is not yet clear in the literature, however, whether informal enterprises become more productive as a result of their production link with the formal sector or whether only the more productive informal enterprises have linkages with the formal sector in the first place. Note that in this paper, we do not focus on the productivity of informal firms. Rather, we are interested in total employment in the different informal sector segments. We argue that modernity of informal enterprises is a useful way to characterize informal sector heterogeneity and use it to distinguish different informal sector segments. We therefore use start-of-period characteristics of firms to measure the modernity of the informal sector in each state-industry, as will be further described in Section 3.

\subsection{Existing evidence for India}

There is a growing empirical literature on the informal manufacturing sector in India, investigating its evolution in terms of spatial and industrial growth patterns. According to Mukim (2011), informal manufacturers in India play an important role in the production of intermediate goods, processed exports and import substitutes, supported by supply side contracts with the formal sector. She studies the location of new informal startups in India and shows that the presence of buyers and suppliers makes a location more attractive for new enterprises. Ghani et al. (2014) find similar evidence. Mukim (2011) further shows that industries with strong input-output linkages have similar spatial employment distributions, and this hold across formal and informal manufacturing. Sundaram et al. (2012) find evidence for complementarity between employment and output in the formal and informal manufacturing sector and suggest this is partly driven by outsourcing from formal to informal firms. These studies clearly indicate that production linkages play an important role for informal manufacturing employment, but they do not explicitly analyze linkages between formal and informal manufacturing. ${ }^{2}$ Furthermore, we are not aware of any studies that account for the differences between modern and traditional segments in the informal sector. 
Regarding the subcontracting activities of formal enterprises, the only available empirical evidence representative of all of Indian manufacturing is a study by Ramaswamy (1999), documenting an increase in subcontracting intensity of formal sector production between 1970 and the early 1990s. In the early 1990s, subcontracting was used most in labor-intensive industries and in industries with the highest average employment per factory. A complete and more up to date picture of formal-informal production linkages in Indian manufacturing is currently lacking, and it therefore remains unclear how formal sector subcontracting is related to the evolution of the informal sector as a whole.

\section{Data and descriptive trends}

\subsection{Data and measurement}

The empirical analysis in this paper is based on nationally representative data for Indian manufacturing enterprises. Data on the formal sector are obtained from the Annual Survey of Industries (ASI), which cover all registered manufacturing establishments, for the years 1994-1995, 2000-2001 and 2005-2006. ${ }^{3}$ Data on the informal sector are obtained from the National Sample Survey (NSS) of unorganized manufacturing for the same three years. The NSS survey covers all unregistered manufacturing establishments including home-based enterprises without any workers other than the owner. All unit level data are aggregated to the state-industry level, with industries defined at the 2-digit level of the National Industrial Classification, as listed in Table 1. In the empirical analysis, we focus on India's 16 major states and the National Capital Territory of Delhi. We have a panel of up to 21 industries in 17 states in 1995, 2001, and 2006, but not all industries are present in all states.

Based on the NSS survey of unorganized manufacturing, we construct three measures of informal sector employment: total state-industry employment, the total number of hired workers, and the total real wage bill. Total employment includes working owners, unpaid family workers, and hired workers, both full- and part-time. Hired workers exclude owners and contributing family workers, and the wage bill recorded in the data refers to the value of total compensation paid to hired workers only (deflated using state- and industry-specific wholesale price indices). We analyze hired workers and the wage bill in order to see whether or not expansion, if any, occurs chiefly through more family members and working owners being drawn into the informal sector, versus actual job creation in informal enterprises.

Formal sector subcontracting, $F S_{i s t}$, is measured as the sum of the purchase value of goods sold in the same condition as purchased and the cost of contract and commission work done by others on materials supplied by the factory. ${ }^{4}$ Both are available at the enterprise level in the ASI data and aggregated by state-industry. The total subcontracting value is deflated in the same way as the informal wage bill. It is important to note that it is not possible to distinguish the proportion of subcontracting directed to informal enterprises in the data: the total value of subcontracting consists of all subcontracting from the formal sector and is an indicator of the size of subcontracting in a given state-industry, whether it is being subcontracted to another formal enterprise or to the informal sector.

Table 2 shows sample descriptive statistics for informal sector employment and formal sector subcontracting. The average state-industry in the sample saw a substantial 
Table 1 Manufacturing 2-digit codes National Industrial Classification 1998

\begin{tabular}{|c|c|}
\hline $\begin{array}{l}\text { NIC } \\
\text { code }\end{array}$ & Industry \\
\hline 15 & Manufacture of food products and beverages \\
\hline 16 & Manufacture of tobacco products \\
\hline 17 & Manufacture of textiles \\
\hline 18 & Manufacture of wearing apparel; dressing and dyeing of fur \\
\hline 19 & Tanning and dressing of leather; manufacture of luggage, handbags, saddlery, harness and footwear \\
\hline 20 & $\begin{array}{l}\text { Manufacture of wood and wood and cork products, except furniture; manufacture of straw articles } \\
\text { and plaiting materials }\end{array}$ \\
\hline 21 & Manufacture of paper and paper products \\
\hline 22 & Publishing, printing and reproduction of recorded media \\
\hline 23 & Manufacture of coke, refined petroleum products and nuclear fuel \\
\hline 24 & Manufacture of chemicals and chemical products \\
\hline 25 & Manufacture of rubber and plastics products \\
\hline 26 & Manufacture of other non-metallic mineral products \\
\hline 27 & Manufacture of basic metals \\
\hline 28 & Manufacture of fabricated metal products, except machinery and equipment \\
\hline 29 & Manufacture of machinery and equipment, n.e.c. \\
\hline 30 & Manufacture of office, accounting and computing machinery \\
\hline 31 & Manufacture of electrical machinery and apparatus n.e.c. \\
\hline 32 & Manufacture of radio, television and communication equipment and apparatus \\
\hline 33 & Manufacture of medical, precision and optical instruments, watches and clocks \\
\hline 34 & Manufacture of motor vehicles, trailers and semi-trailers \\
\hline 35 & Manufacture of other transport equipment \\
\hline 36 & Manufacture of furniture; manufacturing n.e.c. \\
\hline 37 & Recycling \\
\hline
\end{tabular}

Note: industries 23 (coke and petroleum products) and 37 (recycling) are not included in the analysis.

increase in formal sector subcontracting, modest growth in informal sector employment, and a more than doubling of the informal sector wage bill.

A central element of our analysis is the measure of modernity of the informal sector. As Grimm et al. (2012) discuss, various types of segmentation have been identified in different strands of the informality literature, often focusing on two segments: a lowerand an upper-tier segment. In the framework of Ranis and Stewart (1999), the two segments are referred to as the traditional and the modern segment. The modern informal segment is characterized by significant capital per worker, the use of skills and hired

Table 2 Sample descriptive statistics

\begin{tabular}{lllllllll}
\hline Variables & \multicolumn{2}{l}{ Total sample } & $\mathbf{1 9 9 5}$ & & $\mathbf{2 0 0 1}$ & & $\mathbf{2 0 0 6}$ & \\
\hline Subcontracting formal & 20.57 & $(1.97)$ & 20.01 & $(1.82)$ & 20.62 & $(1.99)$ & 21.07 & $(1.95)$ \\
Employment informal & 10.82 & $(2.02)$ & 10.75 & $(1.99)$ & 10.79 & $(2.07)$ & 10.92 & $(2.02)$ \\
Hired workers informal & 9.51 & $(1.92)$ & 9.37 & $(1.93)$ & 9.52 & $(1.91)$ & 9.64 & $(1.93)$ \\
Wage bill informal & 19.35 & $(1.95)$ & 18.96 & $(1.97)$ & 19.37 & $(1.90)$ & 19.73 & $(1.90)$ \\
N & 774 & & 258 & & 258 & & 258 & \\
\hline
\end{tabular}

Note: All variables are in natural logs, and values are in log real Rupees. The table shows unweighted averages across state-industries, with standard deviations in parentheses. Sources: NSS survey of unorganized manufacturing and Annual Survey of Industries. 
labor, and enterprises located outside their owners' homes. They describe certain industries, such as metalworking, as typically modern and others, such as textile handlooms, as typically traditional. In the model of Marjit (2003), the two segments are the laborintensive and the capital-intensive informal sector, where the latter produces an intermediate used by the formal sector and thus expands with formal sector subcontracting.

However, there is no agreement on the definition of modernity, on the relevant number of segments, and the boundaries that define segments. We therefore construct a continuous measure of modernity at the state-industry level using several different characteristics. Following Ranis and Stewart (1999), our modernity measure is based on characteristics of informal enterprises in a given state-industry in 1995, namely the capital-labor ratio (real fixed capital per worker), location (the number of enterprises located outside the owner's household premises, relative to the number of enterprises inside the owner's household), average number of hired workers per enterprise, and the share of enterprises with a technically qualified proprietor.

For each of these four characteristics, the value is standardized across state-industries to have mean zero and a standard deviation of one. The modernity index is then calculated as the simple average of the four standardized values. ${ }^{5}$ The average state-industry thus has a modernity index of zero, while relatively traditional state-industries have negative index values, and modern state-industries have positive index values. Being a continuous measure, the modernity index captures the degree of modernity of each state-industry, relative to all other state-industries. Since we measure modernity based on enterprise characteristics in 1995, the start of the period, it does not vary over time. Subcontracting could of course affect the modernity of the informal sector in a stateindustry, but those impacts are not the focus of our analysis. As explained in Section 2, we are interested in testing whether subcontracting is associated with the expansion of different segments of the informal sector rather than changes in the degree of modernity within those state-industries.

The technical qualification of the proprietor is used as a proxy for education of the owner, but this variable is not available for partnership enterprises involving members from different households and for other non-proprietary enterprises. It is, however, the only education-related variable available in the 1995 data. To check robustness of the results, estimations are also done using a modernity index based only on capital, location, and hired workers.

Tables 3 and 4 summarize the index and its four (non-standardized) components across industries and across states. Across states, on average, the informal tobacco sector is the most traditional industry, followed by the wood industry. In these industries, enterprises have the lowest capital per worker, are almost all located within the household premises, have less than one hired worker per enterprise, and almost no enterprise has a technically qualified owner. Machinery and equipment and motor vehicles are the most modern industries. Considering spatial variation (averaging across industries), states in the north and in the southwest have the most modern informal manufacturing, led by Maharasthra (which includes Mumbai) and Delhi. States in Central and East India, which are also relatively poor, have the most traditional informal sector.

The averages also convey a high correlation between the four components of the modernity index. Correlation coefficients are shown in Table 5. In fact, the components are too highly correlated to include separately in our estimations without running into 
Table 3 Modernity index informal sector, average by industry

\begin{tabular}{|c|c|c|c|c|c|}
\hline Industry & $\begin{array}{l}\text { Capital per } \\
\text { worker }\end{array}$ & Location & $\begin{array}{l}\text { Hired } \\
\text { workers }\end{array}$ & $\begin{array}{l}\text { Qualified } \\
\text { owner }\end{array}$ & $\begin{array}{l}\text { Modernity } \\
\text { index }\end{array}$ \\
\hline Tobacco products & 8.39 & 0.08 & 0.17 & 0.01 & -1.47 \\
\hline Wood and wood and cork products & 9.35 & 0.16 & 0.22 & 0.02 & -0.89 \\
\hline Other non-metallic mineral products & 9.35 & 0.23 & 1.22 & 0.02 & -0.57 \\
\hline Textiles & 9.51 & 0.15 & 0.97 & 0.03 & -0.54 \\
\hline Furniture; manufacturing n.e.c. & 9.80 & 0.32 & 0.53 & 0.03 & -0.41 \\
\hline Leather & 9.91 & 0.33 & 1.04 & 0.03 & -0.31 \\
\hline Food and beverages & 10.18 & 0.44 & 0.60 & 0.01 & -0.22 \\
\hline Metal products & 10.09 & 0.50 & 1.01 & 0.04 & 0.00 \\
\hline Paper and paper products & 10.57 & 0.28 & 1.08 & 0.08 & 0.08 \\
\hline Chemicals and chemical products & 10.44 & 0.42 & 1.50 & 0.09 & 0.11 \\
\hline Machinery and equipment & 10.52 & 0.48 & 0.95 & 0.07 & 0.15 \\
\hline Wearing apparel & 10.15 & 0.30 & 2.58 & 0.15 & 0.18 \\
\hline Basic metals & 10.76 & 0.47 & 1.54 & 0.14 & 0.48 \\
\hline Other transport equipment & 10.70 & 0.61 & 2.00 & 0.11 & 0.48 \\
\hline Rubber and plastics products & 11.05 & 0.62 & 2.12 & 0.11 & 0.50 \\
\hline Publishing and printing & 11.03 & 0.68 & 1.73 & 0.07 & 0.60 \\
\hline Electrical machinery & 10.77 & 0.73 & 2.35 & 0.12 & 0.71 \\
\hline $\begin{array}{l}\text { Radio, television and communication } \\
\text { equipment }\end{array}$ & 10.98 & 0.68 & 2.38 & 0.18 & 0.77 \\
\hline $\begin{array}{l}\text { Medical, precision and optical } \\
\text { instruments }\end{array}$ & 10.75 & 0.64 & 2.95 & 0.20 & 0.82 \\
\hline Motor vehicles & 10.80 & 0.75 & 3.24 & 0.31 & 0.94 \\
\hline $\begin{array}{l}\text { Office, accounting and computing } \\
\text { machinery }\end{array}$ & 10.76 & 0.40 & 7.20 & 0.40 & 0.96 \\
\hline
\end{tabular}

Note: Unit of observation in the analysis is the state-industry; values in this table are averaged across states. Capital per worker is in logs, location is the share of enterprises with a fixed location outside the owner's household, hired workers is the average number of hired workers per enterprise, and qualified owner is the share of proprietary enterprises with a technically qualified owner. The modernity index is the average standardized value, industries are ordered from lowest to highest modernity index.

multicollinearity problems. This confirms that they partly measure the same phenomenon, which is what we intend. We deliberately refrain from analyzing each of the components separately, reflecting the idea that informal sector activities can be modern along different dimensions without necessarily scoring high on each one. For example, a firm with a technically educated owner and a number of additional hired workers can be seen as relatively modern even if production is only moderately capital intensive.

\subsection{Informal employment across segments}

Before turning to our estimation equation, this section describes the expansion of different segments in the informal sector, using quartiles of the modernity index distribution as segment boundaries. Each state-industry has a modernity index value based on 1995 firm characteristics and falls into one quartile of the modernity index distribution: there are roughly 65 state-industries in each quartile. Table 6 shows the distribution of informal sector employment, hired workers, and the total wage bill across quartiles. Total number are given in the bottom row. 
Table 4 Modernity index informal sector, average by state

\begin{tabular}{lccccc}
\hline State & Capital per worker & Location & Hired workers & Qualified owner & Modernity index \\
\hline Orissa & 8.26 & 0.13 & 0.22 & 0.02 & -1.48 \\
Madhya Pradesh & 9.56 & 0.15 & 0.36 & 0.07 & -0.63 \\
Bihar & 9.34 & 0.27 & 0.46 & 0.07 & -0.53 \\
West Bengal & 9.41 & 0.28 & 1.18 & 0.03 & -0.39 \\
Assam & 9.12 & 0.33 & 0.72 & 0.09 & -0.37 \\
Rajasthan & 10.45 & 0.38 & 0.74 & 0.01 & -0.30 \\
Andhra Pradesh & 9.78 & 0.39 & 0.84 & 0.04 & -0.27 \\
Uttar Pradesh & 9.96 & 0.38 & 0.80 & 0.05 & -0.13 \\
Tamil Nadu & 10.27 & 0.36 & 1.54 & 0.03 & -0.09 \\
Karnataka & 9.94 & 0.41 & 1.26 & 0.12 & -0.06 \\
Himachal Pradesh & 10.16 & 0.55 & 0.90 & 0.14 & 0.15 \\
Kerala & 10.16 & 0.54 & 1.65 & 0.12 & 0.28 \\
Haryana & 11.00 & 0.49 & 1.65 & 0.11 & 0.32 \\
Gujarat & 10.62 & 0.61 & 1.51 & 0.05 & 0.33 \\
Punjab & 10.97 & 0.53 & 1.64 & 0.06 & 0.38 \\
Maharashtra & 11.25 & 0.55 & 2.53 & 0.10 & 0.62 \\
Delhi & 11.22 & 0.56 & 3.31 & 0.15 & 0.79
\end{tabular}

Note: Unit of observation in the analysis is the state-industry; values in this table are averaged across states. Capital per worker is in logs, location is the share of enterprises with a fixed location outside the owner's household, hired workers is the average number of hired workers per enterprise, and qualified owner is the share of proprietary enterprises with a technically qualified owner. The modernity index is the average standardized value, states are ordered from lowest to highest modernity index.

Between 1995 and 2006, total employment in informal manufacturing increased from 51.3 to 54.7 million workers. During this period, the share of the first quartile (the least modern) declined, indicating a relatively larger increase in informal sector employment in more modern activities. However, in 2006, the top quartile (the 65 most modern state-industries) still accounted for only eight percent of total informal employment, and the largest share of informal manufacturing employment remains concentrated in the most traditional activities.

The picture for total hired workers in the informal sector (columns four to six) looks somewhat different. As more modern activities include those with more hired workers per enterprise, the relatively modern state-industries account for a much larger share of hired workers than they do for total employment. Compared to total employment, however, there was less change in the distribution of hired workers across quartiles. Both the top and bottom quartile slightly declined in terms of their share in total hired workers.

Finally, the last three columns in Table 6 show the distribution of the wage bill across modernity quartiles. Since family helpers and working owners typically do not receive a wage or salary, this distribution is similar to the distribution of hired workers. An even larger share is accounted for by the top quartiles, indicating that hired workers in more modern activities earn higher wages, which is not surprising given the higher capitalintensity of these activities. As is the case for hired workers, there is no sign of modernization when one considers the total wage bill.

\section{Empirical approach}

We estimate a panel fixed effects model to test whether formal sector subcontracting is related to the size of the informal sector. The key question is whether this relationship 
Table 5 Correlation coefficients across dimensions of modernity

\begin{tabular}{lccccc}
\hline & Capital per worker & Location & Hired workers & Qualified owner & Modernity index \\
\hline Capital per worker & 1 & & & & \\
Location & 0.644 & 1 & & & \\
Hired workers & 0.702 & 0.587 & 1 & 1 & 1 \\
Qualified owner & 0.474 & 0.381 & 0.416 & 0.703 & 1 \\
Modernity index & 0.873 & 0.813 & 0.838 & & \\
\hline
\end{tabular}

Note: $\mathrm{N}=258$. Unit of observation is the state-industry. All variables are in logs and defined as described in the main text.

holds across different segments of the informal sector. As described above, our unit of observation is the state-industry, and each state-industry falls into a particular segment of the informal sector, where segments are defined by the start-of-period modernity of informal enterprises. Because the relevant number of segments and the boundaries between them are unknown, we use the continuous modernity index and estimate the following equation:

$$
\begin{aligned}
\ln \left(Y_{i s t}\right)=\alpha_{\text {is }} & +\gamma_{\mathrm{st}}+\delta_{\mathrm{it}}+\beta_{1} \ln (F S)_{i s t}+\beta_{2} \ln (F S)_{i s t} M_{i s}^{95}+\beta_{3} M_{i s}^{95} I_{01}+\beta_{4} M_{i s}^{95} I_{06} \\
& +\beta_{4} \ln (\mathrm{empF})+\varepsilon_{\text {ist }},
\end{aligned}
$$

where the dependent variable $\ln \left(Y_{i s t}\right)$ is the $\log$ of informal sector employment, hired workers, or the total wage bill in industry $i$ and state $s$, in year $t(1995,2001$, and 2006). The $\alpha_{i s}$ are state-industry fixed effects that capture any time-invariant unobserved heterogeneity. State-time dummies $\left(\gamma_{\mathrm{st}}\right)$ are included to capture unobserved determinants that are common to all industries in a given state, such as different rates of population or economic growth across states and different changes in labor regulation. Additionally, industry-time dummies $\left(\delta_{\mathrm{it}}\right)$ capture unobserved determinants common to all states for a given industry, including tariff reductions and changes in licensing requirements.

Next, $\ln (F S)_{i s t}$ is the log real value of formal sector subcontracting, and $\beta_{1}$ captures the average relationship between formal sector subcontracting and informal sector size. In addition, formal sector subcontracting is interacted with the informal sector modernity index $M_{i s, 95}$. Given that a higher value of the modernity index indicates that the informal sector is more modern, a positive estimate of $\beta_{2}$ would mean that formal sector subcontracting is associated with employment growth in relatively modern informal

Table 6 Informal sector employment, hired workers, and wage bill distribution across

\begin{tabular}{|c|c|c|c|c|c|c|c|c|c|}
\hline \multirow[b]{2}{*}{ Quartile } & \multicolumn{3}{|c|}{ Employment } & \multicolumn{3}{|c|}{ Hired workers } & \multicolumn{3}{|c|}{ Wage bill } \\
\hline & 1995 & 2001 & 2006 & 1995 & 2001 & 2006 & 1995 & 2001 & 2006 \\
\hline $1^{\text {st }}$ & 53.2 & 46.6 & 46.3 & 25.9 & 23.1 & 23.8 & 18.7 & 19.6 & 19.3 \\
\hline $2^{\text {nd }}$ & 25.5 & 29.7 & 28.1 & 28.9 & 33.3 & 29.7 & 21.8 & 27.7 & 24.2 \\
\hline $3^{\text {rd }}$ & 15.4 & 16.0 & 17.7 & 29.5 & 29.9 & 32.3 & 34.3 & 34.0 & 38.1 \\
\hline $4^{\text {th }}$ & 5.9 & 7.6 & 8.0 & 15.7 & 13.7 & 14.2 & 25.3 & 18.7 & 18.4 \\
\hline Total & 100.0 & 100.0 & 100.0 & 100.0 & 100.0 & 100.0 & 100.0 & 100.0 & 100.0 \\
\hline Total (mn.) & 51.3 & 50.4 & 54.7 & 12.0 & 12.2 & 14.5 & 175,915 & 222,590 & 339,879 \\
\hline
\end{tabular}
modernity quartiles

Note: Distribution is in percentages across quartiles, and total value is in million workers or million real Rupees. Sources: NSS survey of unorganized manufacturing 
state-industries, or at least more so than with employment growth in the relatively traditional informal segments. We allow for a direct effect of initial modernity on changes in $\ln \left(Y_{i s t}\right)$ by including an interaction of $M_{i s, 95}$ with year dummies for 2001 and 2006. This term will pick up differential changes in the outcome variable according to the state-industry's initial level of modernity.

In order to allow for nonlinear changes in the effect of outsourcing along the distribution of $M_{i s, 95}$, we also estimate equation (1) with $M_{i s, 95}$ replaced by dummy variables for the four quartiles of its distribution. This is not to suggest that four segments is the relevant number, but rather to check whether the effect of outsourcing changes linearly with informal sector modernity. One could imagine, for example, that both the very traditional and the very modern segments have strong production links with the formal sector, while linkages are weaker in the middle of the distribution. Results are reported for both specifications.

Finally, we control for the log of formal sector employment in the state-industry. This means $\beta_{1}$ and $\beta_{2}$ capture the effects of subcontracting for a given total size of the formal sector. In all, the effect of subcontracting is identified from within-state-industry variation, net of industry-specific and state-specific time trends, and conditional on total formal sector size. The last term $\varepsilon_{i s t}$ in eqn. (1) is a stochastic error term.

We should emphasize again that the estimated effects of formal sector subcontracting can be driven by reverse causality: it may be the case that formal enterprises increase their subcontracting activities in response to an expansion of the informal sector. It would be desirable to use an exogenous source of variation in formal sector subcontracting that is not directly related to informal sector outcomes, to get an unbiased estimate of the causal effect. For lack of such an instrument, however, the estimates cannot be interpreted strictly as causal effects. Yet, even in the extreme case where the causal relationship would run entirely from informal employment to formal subcontracting, the estimates will show which segments of the informal sector are complementary to the formal sector through subcontracting linkages.

\section{Results}

Estimations results are shown in Table 7. The first three columns show estimates of the main effect of formal sector subcontracting and its effect interacted with the modernity index. The last three columns show the effect of formal sector subcontracting in each quartile of the modernity index distribution.

For each dependent variable, the main effect of formal sector subcontracting and its interaction effect with modernity are significantly positive. The main effect estimate indicates that a unit increase in log subcontracting (which is about the average increase between 1995 and 2006) is associated with a 14 percent increase in informal sector employment for the average state-industry. Though this implies a relatively low elasticity, the predicted impact is close to the observed average employment growth from 1995 to 2006 (see Table 2). Figure 2 plots the marginal effect of subcontracting, based on estimates in the first three columns of Table 7, for the entire range of values of the modernity index. The marginal effect is positive and significantly different from zero for state-industries with a modernity index greater than zero, supporting the view that formal-informal production links are concentrated in relatively modern informal sector 
Table 7 Estimation results

\begin{tabular}{lllllll}
\hline & Employment & Hired workers & Wage bill & Employment & Hired workers & Wage bill \\
\hline $\ln (\mathrm{FS})$ & $0.138^{*}$ & $0.234^{* * *}$ & $0.177^{* *}$ & & & \\
& $(0.0710)$ & $(0.0789)$ & $(0.0819)$ & & & \\
$\ln (\mathrm{FS})^{*} \mathrm{M}$ & $0.112^{*}$ & $0.119^{*}$ & $0.124^{*}$ & & & \\
& $(0.0638)$ & $(0.0649)$ & $(0.0635)$ & & & \\
$\ln (\mathrm{FS})^{*} \mathrm{Q} 1$ & & & 0.0175 & 0.119 & 0.0354 \\
& & & $(0.0763)$ & $(0.114)$ & $(0.118)$ \\
$\ln (\mathrm{FS})^{*} \mathrm{Q} 2$ & & & -0.0386 & 0.0311 & -0.0149 \\
& & & $(0.0982)$ & $(0.0952)$ & $(0.101)$ \\
$\ln (\mathrm{FS})^{*} \mathrm{Q} 3$ & & & 0.0963 & $0.305^{*}$ & $0.394^{* *}$ \\
& & & $(0.150)$ & $(0.159)$ & $(0.196)$ \\
$\ln (\mathrm{FS})^{*} \mathrm{Q} 4$ & & & $0.361^{* * *}$ & $0.402^{* * *}$ & $0.277^{* *}$ \\
& & & & $(0.139)$ & $(0.135)$ & $(0.133)$ \\
$\ln ($ formal emp.) & -0.00768 & -0.139 & -0.104 & 0.0293 & 0.0293 & -0.111 \\
& $(0.0878)$ & $(0.111)$ & $(0.108)$ & $(0.0916)$ & $(0.0916)$ & $(0.114)$ \\
Constant & $8.057^{* * *}$ & $5.952^{* * *}$ & $16.37^{* * *}$ & $8.268^{* * *}$ & $6.062^{* * *}$ & $16.16^{* * *}$ \\
& $(1.323)$ & $(1.329)$ & $(1.301)$ & $(1.292)$ & $(1.320)$ & $(1.438)$ \\
Observations & 774 & 774 & 774 & 774 & 774 & 774 \\
R-squared & 0.479 & 0.421 & 0.491 & 0.492 & 0.421 & 0.488 \\
\hline
\end{tabular}

Note: All dependent variables are in logs. All estimations include state-year and industry-year effects and an interaction of the modernity index (or quartile) with year dummies. Standard errors clustered at state-industry level are reported in parentheses below the point estimates; ${ }^{*}$ significant at the .10 level; ${ }^{* *}$ at the .05 level; ***at the .01 level.

segments. Through this link, formal sector subcontracting growth is related to expansion of the relatively modern informal manufacturing segments.

The results of the quartiles specification broadly support these findings. The last three columns in Table 7 show that subcontracting has no effect in the bottom two quartiles and has a strong and significant effect in the most modern quartile, where total employment and hired workers increase by 3.7 percent for a 10 percent increase in subcontracting. In the third quartile, there is a large positive effect on hired work and the wage bill, while the effect on total employment is much weaker and not statistically significant. In all, our results show that in state-industries with a relatively modern informal sector, growth of formal sector subcontracting is associated with informal sector employment growth. The effect on total employment is similar to the effect on the number of hired workers, which suggests that both the increase in the same proportion and the expansion entails job creation in informal enterprises.

Formal sector size has a very small and statistically insignificant effect on informal sector outcomes. By controlling for this variable, we can assure that the relationship between subcontracting and informal sector size does not reflect a third factor driving overall expansion of the state-industry in both the formal and informal sector. Still, we cannot rule out the influence of omitted variables that drive both formal sector subcontracting and informal sector growth for a given size of the formal sector.

Table 8 shows results when we exclude the owner qualification dimension (which is not available for all enterprises in our data) from the modernity index. While the main effect of subcontracting remains significantly positive, the interaction term estimate is lower and no longer significantly different from zero. The marginal effect of subcontracting remains 
a) Employment

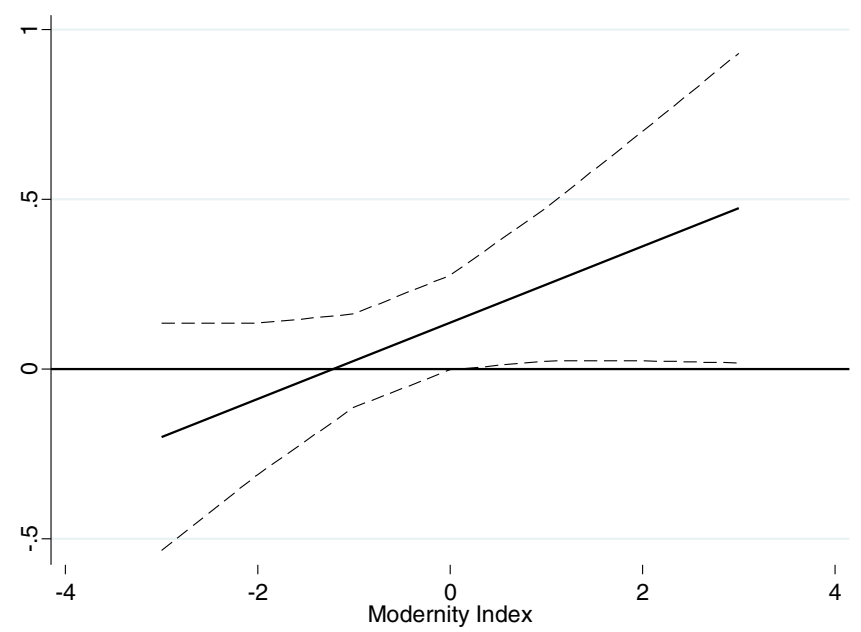

b) Hired workers

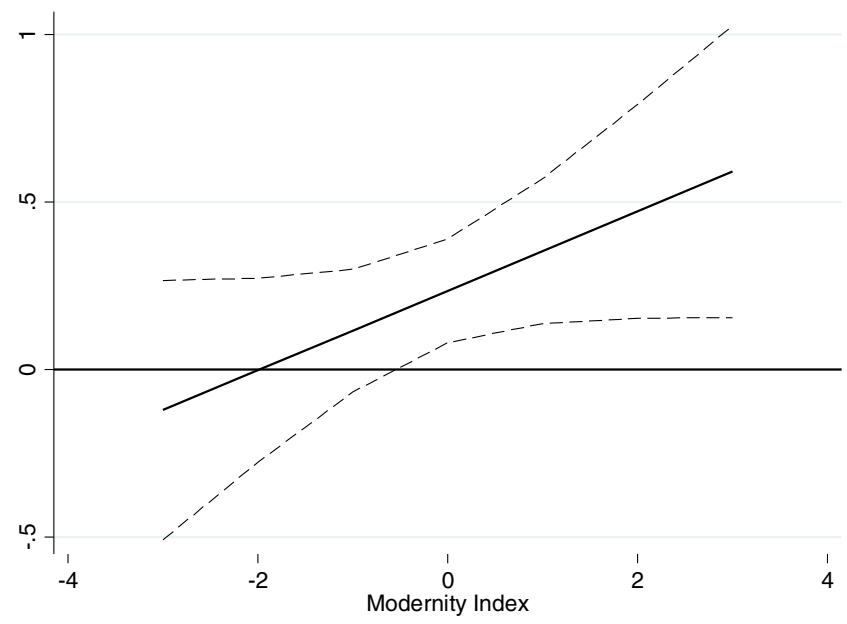

c) Wage bill

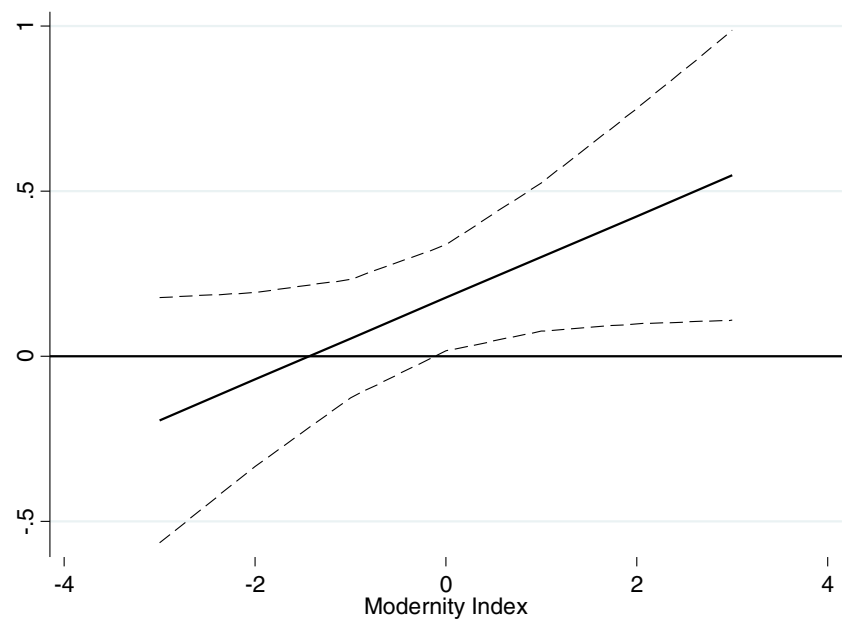

Figure 2 Estimated marginal effect of subcontracting on informal employment (a), hired workers (b), and wage bill (c). Source: Authors' estimations based on NSS survey of unorganized manufacturing and Annual Survey of Industries. 
Table 8 Estimation results, modernity index without owner qualification

\begin{tabular}{|c|c|c|c|c|c|c|}
\hline & Employment & Hired workers & Wage bill & Employment & Hired workers & Wage bill \\
\hline \multirow[t]{2}{*}{$\ln (F S)$} & $0.141^{*}$ & $0.238^{* * *}$ & $0.183^{* *}$ & & & \\
\hline & 0.0726 & 0.0800 & 0.0827 & & & \\
\hline \multirow[t]{2}{*}{$\ln (F S)^{*} M$} & 0.0859 & 0.0696 & 0.0778 & & & \\
\hline & 0.0547 & 0.0574 & 0.0561 & & & \\
\hline \multirow[t]{2}{*}{$\ln (\mathrm{FS})^{*} \mathrm{Q} 1$} & & & & 0.0226 & 0.0921 & -0.0104 \\
\hline & & & & 0.0786 & 0.112 & 0.116 \\
\hline \multirow[t]{2}{*}{$\ln (F S)^{*} \mathrm{Q} 2$} & & & & 0.0804 & $0.214^{*}$ & $0.211^{*}$ \\
\hline & & & & 0.0984 & 0.114 & 0.113 \\
\hline \multirow[t]{2}{*}{$\ln (\mathrm{FS})^{*} \mathrm{Q} 3$} & & & & -0.0305 & 0.118 & 0.167 \\
\hline & & & & 0.114 & 0.135 & 0.168 \\
\hline \multirow[t]{2}{*}{$\ln (\mathrm{FS})^{*} \mathrm{Q} 4$} & & & & $0.334^{* *}$ & $0.377^{* * *}$ & $0.259^{*}$ \\
\hline & & & & 0.139 & 0.139 & 0.139 \\
\hline \multirow[t]{2}{*}{ In(formal emp.) } & -0.00829 & -0.137 & -0.100 & 0.0339 & -0.124 & -0.109 \\
\hline & 0.0873 & 0.108 & 0.105 & 0.0944 & 0.116 & 0.114 \\
\hline \multirow[t]{2}{*}{ Constant } & $7.969^{* * *}$ & $5.837^{* * *}$ & $16.20 * * *$ & $8.265^{* * *}$ & $6.379^{* * *}$ & $16.72^{* * *}$ \\
\hline & 1.361 & 1.370 & 1.341 & 1.186 & 1.279 & 1.335 \\
\hline Observations & 775 & 775 & 775 & 775 & 775 & 775 \\
\hline R-squared & 0.48 & 0.43 & 0.50 & 0.49 & 0.42 & 0.49 \\
\hline
\end{tabular}

significantly positive, however, in the relatively modern informal sector (not shown). In the quartile specification, we still find a large positive effect of subcontracting on employment, hired workers, and the wage bill in the most modern informal sector segment. The coefficients are very similar, and as before, no association is found between formal sector subcontracting and employment in the traditional segments of the informal sector.

\section{Conclusions}

This paper analyzes the relationship between formal sector subcontracting and employment in the informal sector in Indian manufacturing. The existing theoretical literature on this relationship can be classified into two views. The stagnation view argues that formal firms subcontract mainly to the most traditional informal firms (e.g., Portes 1994), while according to the modernization view, formal firms have production linkages only with the modern informal sector (Marjit 2003; Ranis and Stewart 1999).

We contrast these views empirically by testing whether growth of subcontracting is related to expansion of employment in traditional or modern segments of the informal sector using representative data for Indian formal and informal manufacturing enterprises in the period 1995-2006. During this period of rapid economic growth, formal enterprises increasingly subcontracted part of their production process, while employment in informal manufacturing grew substantially, remaining at almost 90 percent of total manufacturing employment. Recent studies by Mukim (2011) and Ghani et al. (2014) have shown that production linkages matter for the location of new informal enterprises and the spatial distribution of formal and informal manufacturing employment in India. The 
present paper, however, is the first to directly assess the role of formal sector subcontracting in the evolution of India's informal manufacturing sector.

In our analysis, we measure modernity of the informal sector at the state-industry level using an index based on start-of-period capital per worker, hired workers per enterprise, the location of enterprises, and technical qualifications of proprietors. Relying on within-state-industry variation and controlling for further unobserved heterogeneity through state-year and industry-year fixed effects, we find a significant positive relationship between formal sector subcontracting and employment in the relatively modern segments of the informal sector.

The results support the modernization view of formal-informal production linkages, according to which formal enterprises subcontract to modern rather than traditional informal sector enterprises. Though total informal manufacturing employment in India remains largely concentrated in relatively traditional state-industries, we find no evidence that employment growth in the most traditional segments of the informal sector is related to growth of formal sector subcontracting. Instead, subcontracting by formal firms is related to expansion of the most modern segments of the informal sector, both in terms of total employment and in terms of hired workers.

A general implication of these results is that the distinction between traditional and modern segments within the informal sector matters empirically and needs to be taken into account in designing employment and industrial policy. More specifically, our analysis implies that policies affecting formal manufacturing enterprises can indirectly impact the modern segment of the informal sector. National and local industrial policies could focus on subcontracting linkages to stimulate job creation in the modern segments of informal manufacturing. Identifying the causal impact of subcontracting on job creation and employment conditions in informal enterprises would evidently be a valuable contribution to the policy debate. For lack of longitudinal enterprise-level data for the informal sector, such empirical evidence is currently not available, but future work in this area can complement the results of this paper.

\section{Endnotes}

${ }^{1}$ The terms 'formal' and 'informal' are not used officially in India. The official distinction is between organized (registered) and unorganized (unregistered) enterprises, where the former consists of enterprises employing 10 or more workers using power, and 20 or more workers without using power. In this article, reference is made to the registered enterprises as formal and all other enterprises - those in the unregistered segment - as informal.

${ }^{2} \mathrm{~A}$ different strand of literature analyzes productivity differences between formal and informal manufacturing in India, showing that informalization of India's economy is slowing down aggregate growth (De Vries et al. 2012) and that liberalization reforms in India increased the productivity of formal as well as informal enterprises, but more so for the former (Khaturia et al. 2013).

${ }^{3}$ In the paper we refer to these as 1995, 2001, and 2006, respectively.

${ }^{4}$ In a similar way, Ramaswamy (1999) measures subcontracting intensity in formal manufacturing. His measure, which is the ratio of the value of goods sold in the same condition as purchased to value added, excludes other forms of subcontracting recorded as contract work performed on materials supplied. 
${ }^{5}$ Our results are the same if we measure the modernity index as the first principal component of the four characteristics.

\section{Competing interests}

The IZA Journal of Labor \& Development is committed to the IZA Guiding Principles of Research Integrity. The authors declare that they have observed these principles.

\section{Acknowledgements}

The authors thank Marcel Timmer for many helpful comments and thank participants at the University of Groningen and the International Institute of Social Studies seminar, the IARIW General Conference, and the IZA/World Bank Workshop on Informal Employment in Emerging and Transition Economies for their input. Any errors are ours. Responsible editor: Hartmut Lehmann

\section{Author details}

'Center for the Study of the Politics and Economics of the Public Sector, Fundação Getulio Vargas, Rua Itapeva 286 São Paulo, Brazil. ${ }^{2}$ Wageningen University, Hollandseweg 1, Wageningen, The Netherlands. ${ }^{3}$ IZA,

Schaumburg-Lippe-Strasse 5-9, Bonn, Germany. ${ }^{4}$ The Conference Board, Chaussée de La Hulpe 178, Brussels, Belgium.

${ }^{5}$ University of Groningen, Nettelbosje 2, Groningen, The Netherlands.

Received: 17 September 2014 Accepted: 13 November 2014

Published online: 18 December 2014

\section{References}

Arimah BC (2001) Nature and determinants of the linkages between informal and formal sector enterprises in Nigeria. Afr Dev Rev 13(1):114-144

Boehme M, Thiele R (2012) Informal-formal linkages and informal enterprise performance in urban west africa. Eur J Dev Res 26:473-489

Davies R, Thurlow J (2010) Formal-informal economy linkages and unemployment in South-Africa. S Afr J Econ 78(4):437-459

De Vries GJ, Erumban AA, Timmer MP, Voskoboynikov I, Wu HX (2012) Deconstructing the BRICs: structural transformation and aggregate productivity growth. J Comp Econ 40(2):211-227

Ghani E, Kerr WR, O'Connell SD (2014) Spatial Determinants of Entrepreneurship in India. Regional Studies 48(6):1071-1089

Ghani E, Kerr WR, O'Connell SD (2013) The Exceptional Persistence of India's Unorganized Sector. Policy Research Working Paper No. 6454, World Bank, Washington, D.C.

Grimm M, Knorringa P, Lay J (2012) Constrained gazelles: high potentials in west Africa's informal economy. World Dev 40(7):1352-1368

Hart K (1973) Informal income opportunities and urban employment in Ghana. J Mod Afr Stud 11(1):61-89

House WJ (1984) Nairobi's informal sector: dynamic entrepreneurs or surplus labor? Econ Dev Cult Change 32(2):277-302

ILO \& WTO (2009) Globalization and Informal Jobs in Developing Countries. ILO and WTO, Geneva

Khaturia V, Rajesh Raj SN, Sen K (2013) The effects of economic reforms on manufacturing dualism: evidence from India. J Comp Econ 41(4):1240-1262

Kotwal A, Ramaswami B, Wadhwa W (2011) Economic liberalization and Indian economic growth: What's the evidence? J Econ Lit 49(4):1152-1199

Marjit S (2003) Economic reform and informal wage - a general equilibrium analysis. J Dev Econ 72:371-378

Mazumdar D, Sarkar S (2008) Globalization, Labour Markets and Inequality in India. Routledge, New York

Moser CN (1978) Informal sector or petty commodity production: dualism or dependence in urban development. World Dev 6:1041-1064

Mukim M (2011) SERC Discussion Paper 72. Centre, Spatial Economics Research, Industry and the urge to cluster: a study on the informal sector in India

Portes A, Castells M, Benton LA (1989) The Informal Economy: Studies in Advanced and Less Developed Countries. Johns Hopkins University Press, Baltimore

Portes A (1994) When More Labor can be Less: Labor Standards, Development and the Informal Economy. In: Rakowski C (ed) Contrapunto. The informal sector debate in Latin America. State University of New York Press, Albany

Ramaswamy KV (1999) The search for flexibility in Indian manufacturing, New evidence on subcontracting activities. Econ Pol Wkly 34(6):363-368

Ranis G, Stewart F (1999) V-goods and the role of the urban informal sector in development. Econ Dev Cult Change 47(2):259-288

Schneider F, Buehn A, Montenegro CE (2010) New estimates for the shadow economies all over the world. Int Econ J 24(4):443-461

Siggel E (2010) The Indian informal sector: the impact of globalization and reform. Int Labour Rev 149(1):93-105

Sundaram A, Ahsan RN, Mitra D (2012) Complementarity Between Formal and Informal Manufacturing in India. In: Bhagwati J, Panagariya A (eds) Reforms and Economic Transformation in India. Oxford University Press, USA

Tokman VE (1978) An exploration into the nature of informal-formal sector relationships. World Dev 6(9-10):1065-1075

Watanabe S (1971) Subcontracting, industrialization and employment creation. Int Labour Rev 104(1\&2):51-76

Wattanapruttipaisan T (2002) SME subcontracting as bridgehead to competitiveness: framework for an assessment of supply-side capabilities and demand-side requirements. Asia-Pac Dev J 9(1):65-87

Weeks J (1975) Policies for expanding employment in the informal urban sector of developing economies. Int Labour Rev 111:1-13

doi:10.1186/s40175-014-0022-2

Cite this article as: Moreno-Monroy et al:: Formal sector subcontracting and informal sector employment in

Indian manufacturing. IZA Journal of Labor \& Development 2014 3:22. 